\title{
A New Methodology to Analysis and Predict Shoreline Changes Due to Human Interventions (Case Study: Javad Al-Aemmeh port, Iran)
}

\section{Seyyed Meysam Rezaee ${ }^{1}$, Aliasghar Golshani ${ }^{2 *}$, Seyed Hosein Mousavizadegan³}

1 Department of Maritime Engineering, Amirkabir University of Technology, Tehran, Iran; meysam.rezaee@aut.ac.ir

2* Department of Civil Engineering, Tehran Azad University, Central Branch, Tehran, Iran; ali.golshani@iauctb.ac.ir

3 Department of Maritime Engineering, Amirkabir University of Technology, Tehran, Iran; hmousavi@aut.ac.ir

\section{ARTICLE INFO}

Article History:

Received: 8 Mar. 2019

Accepted: 2 Jul. 2019

\section{Keywords:}

Historical trend

Digital Shoreline Analysis System (DSAS)

LITLINE

End Point Rate (EPR)

Linear Regression Rate (LRR)

\begin{abstract}
In recent years, determining the rate of shoreline change by its historical trend has been reported frequently. This study has focused on shorelines at the adjacency of Javad Al-Aemmeh port which has undergone successive constructions in its region. The decadal trend of studied shoreline change was determined by the historical trend method. A numerical method was also employed to reduce the probable deficiencies concerned to these constructions. Accordingly, for the first time, a framework was developed to compare the results of historical trend and numerical methods with a field-measured value both spatially and quantitatively and based on this comparison, the most suitable rate of change was assigned to each coastal landform. Finally, it was revealed that among the computed rates, the Linear Regression Rate (LRR) from historical trend method has given the best estimation for the shoreline change rate, but in those parts which the shoreline was directly under influence of human interventions the change rate derived from the numerical method has been more accurate. Besides, results showed that at those parts which the Net Shoreline Movement (NSM) and the Shoreline Change Envelope (SCE) are identical, predicting the future position of shoreline by its past trend is more reliable.
\end{abstract}

\section{Introduction}

The shoreline term indicates the soil-water contact line at a particular time [1,2]. Shoreline "is one of the most important linear features on Earth's Surface" [3]. It is well known that during the time, due to natural processes (e.g. water surface change, climate change, breaking waves, wave-induced currents, storms and etc.) and human intervention in coastal zones (port constructions, coast-protection structures, dredging, ship-induced waves), shorelines would take changes constantly in shape and position in response to these changes $[4,5]$.

Surely to adopt effective management decisions in coastal areas, a thorough understanding of coastal processes which leads to predict shoreline evolutions with a level of confidence, is inevitable. This issue challenges coastal scientists as well as engineers to derive sufficient knowledge for such predictions [6$11]$.
In recent years, several methods have been established to determine and predict shoreline changes [12]. Among them, using the historical trend to determine shoreline changes (related to average annual erosion rates) and keeping the linear trend to forecast further changes, is the most typical one. But "the intrinsic uncertainty of using a simple linear technique to model the stochastic nature of the climatic forcing is obvious" [13] which imposes additional concerns to apply this method. Moreover, determining shoreline changes by using the historical trend method includes significant uncertainties when a new structure is constructing in the coastal zones. This is because of the large impacts that coastal structures have on coastal processes and shorelines both up-drift and down-drift of themselves $[11,14,15]$.

Javad Al-Aemmeh fishery port located along the north coast of the Persian Gulf is a good example of coastal areas which have experienced successive constructions in their region. Consequently, determining the 
shoreline changes in that area by using the historical trend method seems to be inaccurate at some levels. The present study aims to employ a numerical method (besides the historical trend method) to cover the aforementioned uncertainties of historical trend method in determining the shoreline changes at the adjacency of the Javad Al-Aemmeh port.

Regarding the spatial dimensions of sediment transportation, there are different approaches in numerical studies of shoreline evolutions: The one-line (1D) models which do not consider the cross-shore sediment transportation; The two-dimensional (2D or field) models which include the 2DH and 2DV models with horizontal and vertical computational grids, respectively; The quasi-three dimensional models which employ some of the two-dimensional features to facilitate computations (e.g. $[16,17])$; The threedimensional which are the most sophisticated models and describe water levels, wave action and currents over a 3D grid by solving the continuity and motion equations (e.g. [18]).

The one-line models are "typically run to investigate shoreline change over distances of from one to tens of kilometres and for time intervals of months to longer than 10 years" [14]. Spatial and temporal conditions of the current study shoreline fulfil the required criteria of the one-line models. Hence, a one-line model has used to assist the historical trend model in this study.

Through a framework developed for the first time in this study, results of the historical trend and the numerical methods were compared spatially and statistically to a field-measured shoreline, in order to reveal their accuracy in determining the shoreline changes. The studied shoreline with the length of about $5.5 \mathrm{~km}$ includes a variety of natural landforms and some human-made structures which challenges comparison of these methods more than studies with a single type of landforms. Eventually, a single shoreline for the area was predicted by assigning the best results of each method to each coastal landform rather than using just the historical trend or just the numerical method.

\section{Literature review}

Since today, plenty of shoreline change and sediment transportation studies have been conducted by other researchers. An investigation into these studies reveals that they can be classified by their method of research. Table 1 was prepared to show this classification. In addition, since in these studies, the inclusion or exclusion of the structure influences on the surrounding shorelines is considerably important, it was remarked in Table 1, too.

As it can be seen from Table 1, a comprehensive study which uses the numerical modeling alongside with the remote sensing technique and doing a verification by comparing the results with field measurements has not been performed yet. Besides, none of these studies provide a clear estimation for the future evolutions of the shorelines. In contrary, the presented study has aimed to make a comparison between the numerical method and the use of remote sensing in studying shoreline change issue to reveal the accuracy and benefits of each method in predicting the future changes.

Again, it should be noticed that the study area in this research contains different types of coastal landforms and successive constructions have been taken place in that region during the time span of study. This approach would enhance the contribution of these studies.

Table 1. Studies which has been accomplished by other researchers classified based on their research method

\begin{tabular}{|c|c|c|c|c|}
\hline Researcher(s) & $\begin{array}{l}\text { Numerical } \\
\text { Modeling }\end{array}$ & $\begin{array}{l}\text { Remote } \\
\text { Sensing }\end{array}$ & $\begin{array}{l}\text { Field and/or } \\
\text { Laboratory }\end{array}$ & $\begin{array}{l}\text { Including } \\
\text { Structural effects }\end{array}$ \\
\hline $\begin{array}{c}\text { Siegle et al. [19], Lumborg \& Windelin [20], Merriit et al. [21], } \\
\text { Lumborg \& Pejrup [22], Elis \& Stone [23], Van Maren [24], Hu } \\
\text { et al. [25], Kamalian \& Safari [26], Eisaei M. \& Hakimzadeh } \\
\text { [27], Khalifa et al. [28] }\end{array}$ & $\checkmark$ & - & - & - \\
\hline $\begin{array}{c}\text { Deguchi \& Sawaragi [29], Rosati \& Kraus [30], Suresh \& Sundar } \\
\text { [31], Tajziehchi \& Shariatmadari [32], Saengsupavanich [33], } \\
\text { Kristensen [34], Noujas et al. [35] }\end{array}$ & $\checkmark$ & - & - & $\checkmark$ \\
\hline $\begin{array}{l}\text { DeWitt et al. [36], Alesheikh et al. [37], Alesheikh et al. [3], } \\
\text { Naeimi N.A. et al. [38], Ardeshiri L. \& Moradi [39], Baharlouei } \\
\text { \& Maafi G. [40] }\end{array}$ & - & $\checkmark$ & - & - \\
\hline Ari et al. [41], Rajasree et al. [42] & $\checkmark$ & $\checkmark$ & - & - \\
\hline Nielsen et al. [43], Li et al. [44], Leroy [45], Allyev [46] & - & - & $\checkmark$ & - \\
\hline $\begin{array}{l}\text { Hosseini N. [47], Nadimi \& Lashtehneshaei [48], Taghvaei \& } \\
\text { Ghiasi [49] }\end{array}$ & $\sqrt{ }$ & - & $\checkmark$ & - \\
\hline Lillesand et al. [50], Sulis et al. [51] & - & $\checkmark$ & $\checkmark$ & - \\
\hline Zarifsanayei \& Zaker [52] & $\sqrt{ }$ & - & $\sqrt{ }$ & $\sqrt{ }$ \\
\hline Jafarzadeh et al. [53] & $\checkmark$ & $\checkmark$ & - & $\checkmark$ \\
\hline
\end{tabular}




\section{Study area}

The westernmost county of Hormozgan province in Iran, Parsian (formerly known as Gavbandi), has 1500 fishers which are fishing near 6500 tons of aquatic species each year. Moreover, about $15 \%$ of the 50,000 residents of the county are working in the fishing industry. The Javad Al-Aemmeh fishery port located in Parsian county by covering more than 530 fishers and berthing 109 fishing as well as 50 merchant vessels, plays an important role in the local economy $[54,55]$.

The location of Parsian County in Hormozgan Province of Iran and the studied shoreline at the adjacency of Javad Al-Aemmeh fishery port are illustrated in Figure 1. Geographical coordinates of the studied shoreline differ from $52^{\circ} 57^{\prime} 48^{\prime \prime}$ East longitude and $27^{\circ} 08^{\prime} 30^{\prime}$ ' North latitude (point [A] in Figure 1) to $53^{\circ} 00^{\prime} 23^{\prime \prime}$ East longitude and $27^{\circ} 07^{\prime} 29^{\prime \prime}$ North latitude (point [B] in Figure 1).

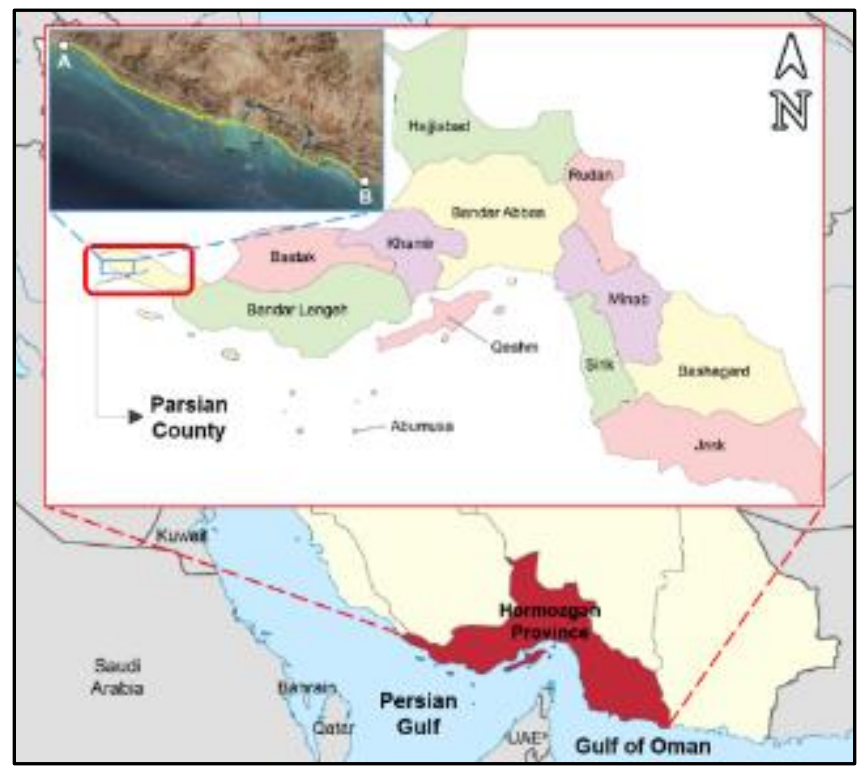

Figure 1. Location of the study area

To explain an advantage of Javad Al-Aemmeh port's location, it is worth mentioning that a vessel from the port can reach the International waters within a 10minute sailing. Distances between Javad Al-Aemmeh port and major ports of the Persian Gulf are presented in Table 2 [56].

Table 2. Location of Javad Al-Aemmeh relative to the major ports of Persian Gulf [21].

\begin{tabular}{cccc}
\hline Port Name & $\begin{array}{c}\text { Location } \\
\text { (Country) }\end{array}$ & $\begin{array}{c}\text { Distance } \\
\text { (Nautical mile) }\end{array}$ & $\begin{array}{c}\text { Sailing } \\
\text { Route }\end{array}$ \\
\hline Ras Tanura & Saudi Arabia & 157 & Straight \\
\hline Kuwait & Kuwait & 300 & 1 Deviation \\
\hline Bahrain & Bahrain & 140 & Straight \\
\hline Doha & Qatar & 135 & Straight \\
\hline Abu Dhabi & $\begin{array}{c}\text { United Arab } \\
\text { Emirates }\end{array}$ & 174 & Straight \\
\hline Dubai & $\begin{array}{c}\text { United Arab } \\
\text { Emirates }\end{array}$ & 165 & 1 Deviation \\
\hline
\end{tabular}

\begin{tabular}{cccc}
\hline $\begin{array}{c}\text { Bandar } \\
\text { Lengeh }\end{array}$ & Iran & 116 & 2 Deviation \\
\hline $\begin{array}{c}\text { Shahid } \\
\text { Bahonar }\end{array}$ & Iran & 199 & 2 Deviation \\
\hline Asaluyeh & Iran & 33 & 1 Deviation \\
\hline
\end{tabular}

Today, the Javad Al-Aemmeh fishery port is composed of two different basins which are developed separately during the years. At first, a combination of a valley called the Had-Kooh and an ancient bay which is filled up today and is called the Kharabeh had formed a natural basin. In the year of 1984 by implementing some changes to the natural basin as well as constructing berthing facilities, the port (part [a] in Figure 2) was established to serve local fishers [56]. In 2001, Iran Fishery Organization started to study about the port and recognized that the length of breakwater arms (part [b] in Figure 2) is not long enough to prevent sediment penetration into the port's entrance canal. Length of the western and the eastern breakwater arms was 95 and $125 \mathrm{~m}$, respectively. After the modification, they became 305 and $280 \mathrm{~m}$ long each [57].

In 2005, a new port yard (part [c] in Figure 2) with an area of 2 hectares was built in the vicinity of the east arm to speed-up the fish loading/unloading operation. Later in 2011, new breakwaters of length $850 \mathrm{~m}$ (west breakwater) and $315 \mathrm{~m}$ (east breakwater) were constructed by the port development program to provide a 25 hectares basin (part [d] in Figure 2) with the aim of increasing the port capacity [58].

The tidal range in this area is $1.25 \mathrm{~m}$ based on analyzing the available dataset of National Cartographic Center of Iran. The Mean Higher High Water (MHHW) is 1.7 $\mathrm{m}$ while the Mean Lower Low Water (MLLW) is 0.45 $\mathrm{m}$ and the Mean Tide Level (MTL) is near $1.1 \mathrm{~m}$ [59]. According to the Monitoring and Modeling Studies of Iranian Coasts (phase4-Hormozgan coasts), the average wind speed and wind direction in this region are $10 \mathrm{~m} / \mathrm{s}$ and 45 degrees azimuth, respectively which result in wind shear stress of $10^{-3} \mathrm{~m}^{2} / \mathrm{s}$. The local currents in the area (not the wave-driven currents), by average, have the velocity of $0.5 \mathrm{~m} / \mathrm{s}$ beyond the $4 \mathrm{~m}$ depth contour with the roughness of $0.02 \mathrm{~m}$ [60].

Interpretation of Google Earth Landsat images from 2005 to 2015 revealed that the studied shoreline in January 2005 was made up of 5 different types of coastal landforms. Sandy beaches which covered about $1.63 \mathrm{~km}$ of the shoreline, were the dominant landform in January 2005. Regarding their length, other landforms were $1.60 \mathrm{~km}$ of coastal reefs, a continued rocky cliff with the length of $1.29 \mathrm{~km}$, two adjacent tombolos that occupied $578 \mathrm{~m}$ of the shoreline, and two pieces of sandy beaches which were formed by blockage of sediments next to the coast normal breakwaters and together had $354 \mathrm{~m}$ length. These landforms are illustrated in Figure 3. 


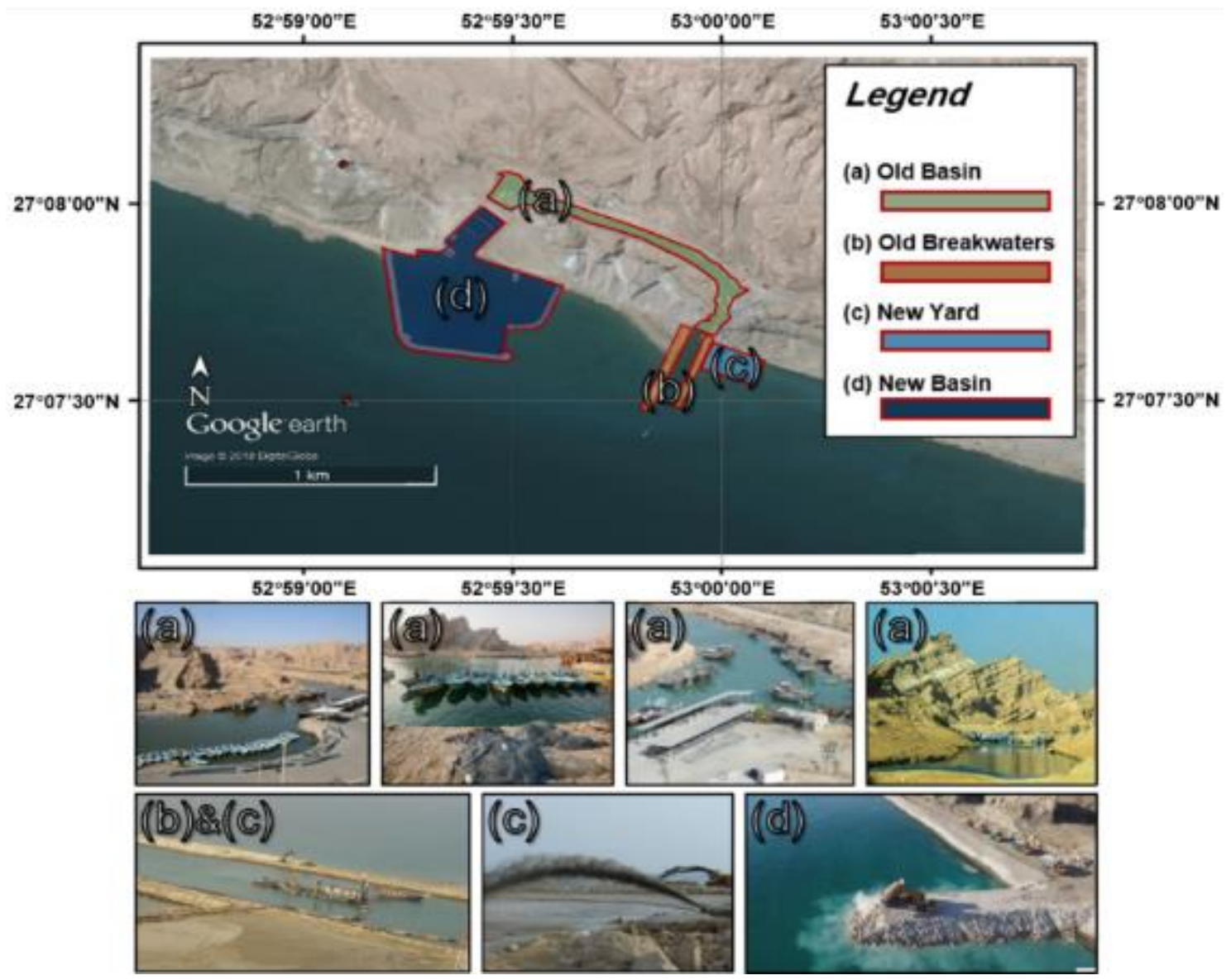

Figure 2. Locations and pictures of; (a): old basin of the port established in 1984, (b): breakwater arms of the old basin modified in 2001, (c): new port yard constructed in 2005, (d): new breakwater arms and basin constructed in 2011.

\section{Materials and methods}

Since the current study has employed two different methods, datasets of each method and their modeling procedures are presented separately in this section. Before entering into the modeling details, the concept regarding the methodology of this study is provided in the following paragraphs.

\subsection{Concept}

As the first step, shorelines of studied area were digitized from available satellite images. Afterward, the rate of shoreline change was calculated using the End Point Rate (EPR) and Linear Regression Rate (LRR) methods. At the same time, the shoreline change of area was computed numerically in one hour time steps. The rate of shoreline change related to the numerical method was calculated too.

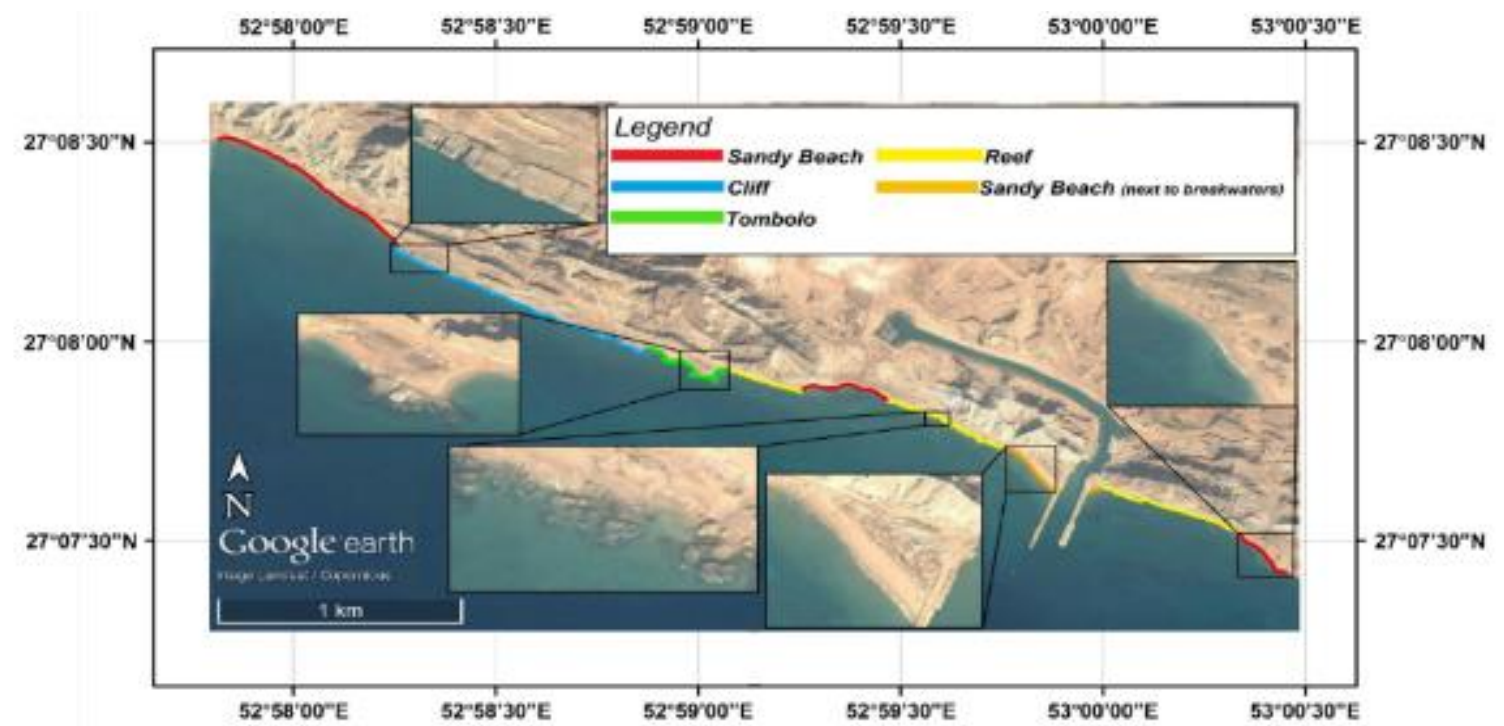

Figure 3. Coastal landforms of the studied shoreline (the background image is referred to March 2005 satellite image). 
The digitized shoreline of the first proper satellite image of the studied area $(01 / 01 / 2005)$ was considered as the first known state of shoreline in the model. The other known state of shoreline was a field-measured shoreline related to the year 2009. Therefore, based on the change rates calculated earlier, shoreline position of 2005 was updated to make an estimation for 2009 position (separately for each rate of change and each coastal landform). By comparing the field-measured shoreline with estimated shorelines, the accuracy of each rate of change in predicting the shoreline position was achieved. Subsequently, for each landform, the best rate of change was selected which benefits from either the historical trend or the numerical method.

Through this procedure, deficiencies of historical trend method in determining shoreline change of areas which are constantly under human interventions would be covered by the numerical method. Ultimately, the digitized shoreline related to the last available satellite image (04/24/2017) was compared with a shoreline predicted by this procedure. Results of the final comparison were satisfactory in most of the landforms. The methodology flowchart of the research is illustrated in Figure 4.

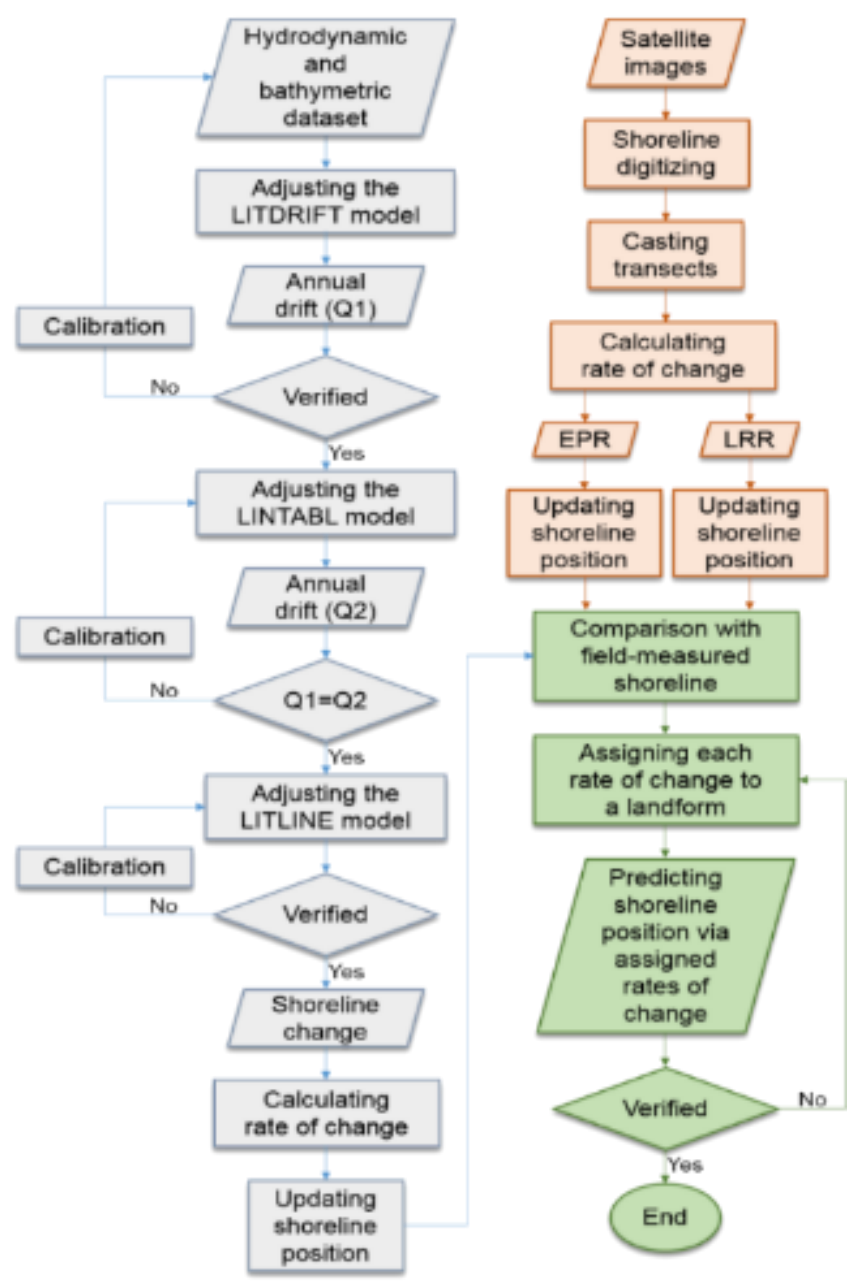

Figure 4. Workflow diagram of the research. The purple and the orange colored shapes represent the modeling procedure of the numerical method and the historical trend method, respectivelv.

\subsection{Historical trend method}

Through the years, several systems have been established to provide the dataset of shoreline analyzing via the historical trend method. Beside the well-known systems, the LiDAR surveying, video images [61], infrared camera based imaging [62], UAV and drone system [63], synthetic aperture radar [64-66] and marine navigation radar [67] are some of these systems [12, 68, 69].

The investigation of selecting the proper system usually is done by considering the time efficiency, area coverage, economic priority and availability of historical images for a specific region. Eventually, utilizing the satellite remote sensing is preferred for data acquisition in coastal projects which are supported by low budgets in developing countries $[5,7,11,69$ 71].

\subsubsection{Shoreline digitizing}

To specify shoreline positions, several indicators such as the vegetation line, the high water line (HWL) and the low water line (LWL) can be used [68]. The vegetation line did not exist all over the shoreline extend and the LWL cannot be traced on satellite images. Therefore, the HWL which can be easily identified by the wet/dry line was used for shoreline digitizing. The HWL is a valid indicator which has been used frequently in coastal researches [69, 72].

Historical images of the area were obtained from Google Earth software. Some of the images were ignored in shoreline rate of change calculation because they do not cover the entire shoreline in a specific date and, the last updated image preserved to be compared with the final prediction. Information about these images is presented in Table 3.

Table 3. Available satellite images of the area and their application in the current study.

\begin{tabular}{cccc}
\hline $\begin{array}{c}\text { Imagery } \\
\text { No. }\end{array}$ & $\begin{array}{c}\text { Imagery } \\
\text { date }\end{array}$ & $\begin{array}{c}\text { Coverage } \\
\text { status }\end{array}$ & $\begin{array}{c}\text { Application in } \\
\text { study }\end{array}$ \\
\hline 1 & $02 / 27 / 2003$ & $\begin{array}{c}\text { Part of the } \\
\text { shoreline }\end{array}$ & Ignored \\
\hline 2 & $01 / 01 / 2005$ & $\begin{array}{c}\text { Entire } \\
\text { shoreline }\end{array}$ & $\begin{array}{c}\text { Rate of change } \\
\text { calculation }\end{array}$ \\
\hline 3 & $08 / 14 / 2011$ & $\begin{array}{c}\text { Part of the } \\
\text { shoreline }\end{array}$ & Ignored \\
\hline 4 & $10 / 09 / 2011$ & $\begin{array}{c}\text { Entire } \\
\text { shoreline }\end{array}$ & $\begin{array}{c}\text { Rate of change } \\
\text { calculation }\end{array}$ \\
\hline 5 & $02 / 15 / 2015$ & $\begin{array}{c}\text { Entire } \\
\text { shoreline }\end{array}$ & $\begin{array}{c}\text { Rate of change } \\
\text { calculation }\end{array}$ \\
\hline 6 & $08 / 25 / 2015$ & $\begin{array}{c}\text { Entire } \\
\text { shoreline }\end{array}$ & $\begin{array}{c}\text { Rate of change } \\
\text { calculation }\end{array}$ \\
\hline 7 & $04 / 24 / 2017$ & $\begin{array}{c}\text { Entire } \\
\text { shoreline }\end{array}$ & Final prediction \\
\hline
\end{tabular}

Although it should be noticed that these (historical) Google Earth images are not georeferenced precisely. It can be seen from the location of old breakwaters. Hence, for each historical image, several control points were marked on the tip of breakwater arms. The total 
Root Mean Square (RMS) error of georeferencing these control points was obtained $1.9 \mathrm{~m}$.

Extraction of shorelines from satellite images was carried out manually using visual interpretation. The wet/dry line was marked by "Add Path" tool of Google Earth software and then converted into a shape-file by using an on-screen technique reported by Brown [73]. This technique enables the user to zoom and rotate around the wet/dry line position and check them from different viewpoints without losing the image resolution rather than downloading large-scale raster images and generating vector shorelines.

\subsubsection{Shoreline rate of change calculation}

The digitized shorelines of images number 2, 4, 5 and 6 from Table 3 were used to calculate the shoreline rate of change using the Digital Shoreline Analysis System (DSAS) v.4.3. DSAS is a freely available extension of Geographic Information System (ArcGIS) software which is developed by the United States Geological Survey (USGS). Detailed descriptions about DSAS have been provided by Thieler et al. [68] and addressed by Manca et al. [74].

Regarding the time span which the satellite images are available, changes in the cliff part and the tombolos head parts (illustrated in Figure 3) cannot be evaluated accurately in such a relatively short time span and then these parts were omitted from analysis.

The uncertainty value as a major input of the DSAS is related to the reliability of the output rates of change. This value is calculated based on sampling, measurement and statistical errors of compiling each shoreline position [68, 72, 75]. After Jonah et al. [72], to calculate the uncertainty value, three uncertainty terms related to this study were considered according to Hapke et al. [6]. They are georeferencing uncertainty $\left(U_{g}\right)$, digitizing uncertainty $\left(U_{d}\right)$ and the HWL uncertainty at the time of survey $\left(U_{p d}\right)$.

Value of georeferencing uncertainty was obtained earlier $1.9 \mathrm{~m}$. The digitizing uncertainty and the HWL uncertainty values were chosen from Hapke et al. [6] (following Jonah et al. [72]) which are $1 \mathrm{~m}$ and $4.5 \mathrm{~m}$ respectively. The total uncertainty value $\left(U_{p}\right)$ is calculated from Eq.(1) and the end point shoreline change uncertainty for a single transect $\left(U_{E}\right)$ is from Eq.(2).

$U_{p}=\sqrt{U_{g}^{2}+U_{d}^{2}+U_{p d}^{2}}$

$U_{E}=\frac{\sqrt{U_{1}^{2}+U_{2}^{2}}}{\text { year } 2-\text { year } 1}$

Where terms of $U_{1}$ and $U_{2}$ in Eq.(2) are the total uncertainty value for each shoreline position. Therefore based on Eq.(1), the total uncertainty value for each

${ }^{* 1}$ The WLR and the LMS approaches would not take value since the uncertainty value for all shoreline positions is identical. shoreline position was obtained $4.98 \mathrm{~m}$ which is identical for all digitized shorelines since their extraction technique was the same. Moreover, the annualized uncertainty value at each transect was calculated by Eq.(2) as $\pm 0.66 \mathrm{~m}$. Calculation of the annualized uncertainty value was accomplished by considering the first and the last digitized shorelines for terms of $U_{1}$ and $U_{2}$ as well as yearl and year 2 .

To adjust the DSAS model, a baseline which is complied with the general direction of shoreline (i.e. azimuth of 110 degrees), was placed onshore and next to the port canal. The number of 465 transect lines with $10 \mathrm{~m}$ space and $1300 \mathrm{~m}$ length were set to intersect each shoreline (Figure 5) and the uncertainty value was calculated $4.98 \mathrm{~m}$ earlier. The calculation statistics were run in Shoreline Change Envelope (SCE), Net Shoreline Movement (NSM), End Point Rate (EPR), and Linear Regression Rate (LRR) approaches ${ }^{* 1}$.

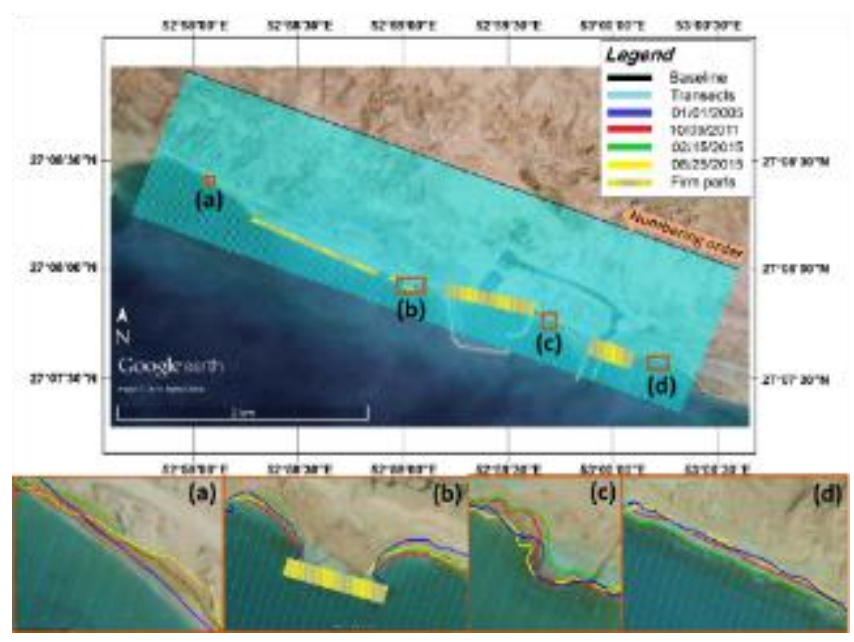

Figure 5. The baseline, transect lines, and digitized shorelines. Cliff parts and human-made structures which cannot be analyzed considering the investigation period were illustrated as "Firm parts" and excluded from calculations.

\subsection{Numerical method}

As it was mentioned earlier in the introduction section, since the shoreline of the current study by the length of near $5.5 \mathrm{~km}$ was investigated for time intervals of almost 12 years, according to Sorensen [14] the oneline models are suitable for being employed in this study. In one-line models, by considering a small section of a sandy beach (Figure 6) in the zones that the longshore transport is active, the continuity equation for the beach sediment can be written in the way that the change in the beach section volume would be equal to the net longshore transport of sediment into and out of the mentioned section, Eq.(3). 


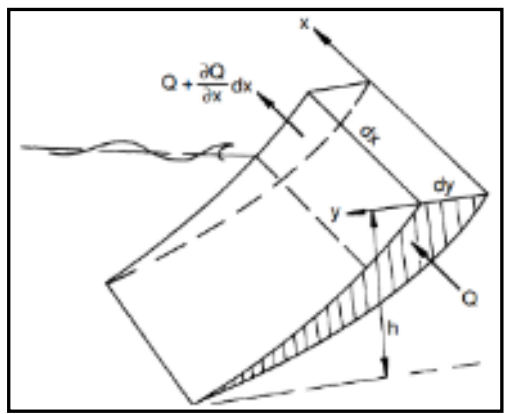

Figure 6. The section for developing sediment continuity equation [14].

$Q-\left(Q+\frac{\partial Q}{\partial x} d x\right)=\frac{h d x d y}{d t}$

$\frac{d Q}{d x}+h \frac{d y}{d t}=0$

Therefore by dividing the shoreline to short segments and refracting the offshore waves to the shoreline, over the time interval, $d_{t}$, the longshore transport rate at the boundary of each segment can be calculated. Then, by applying Eq.(3) retreat or accretion of the shoreline in that segment would be achieved. The process is repeated until the last time interval updates the new shoreline position of all segments.

\subsubsection{Modeling Procedure}

The studied shoreline evolutions were investigated numerically through the contribution of Littoral Processes and Coastline Kinetics (LITPACK) modeling system developed by the Danish Hydraulic Institute (DHI). Coastline evolution (LITLINE) is one of the LITPACK's main modules which benefits from the one-line theory of shoreline change. LITLINE solves the continuity equation by using an implicit Crank-Nicholson scheme which gives the shoreline position changes in time [76].

Necessary datasets for numeric modeling of shoreline evolutions near the Javad Al-Aemmeh port were obtained from Monitoring and Modeling Studies of Iranian Coasts (phase4-Hormozgan coasts) which provides data for Iran's Integrated Coastal Zone Management (ICZM) program [60]. The wave-climate dataset from January 1999 to December 2009 was available in every one hour time step. This dataset includes the records of wave specifications, mean water level, spreading factor, local current's speed, wind specifications, and a cross-shore profile described by 43 grid points in one-meter steps covering depth of 21.61 to $+2.12 \mathrm{~m}$. Furthermore, an estimation for annual sediment drift concerning to the years 1999 to 2006, and, a 2009 field-measured shoreline marked by the HWL indicator were provided as calibration/verification data. Wave condition of the years 1999 to 2006 is presented in Figure 7 via a roseplot.

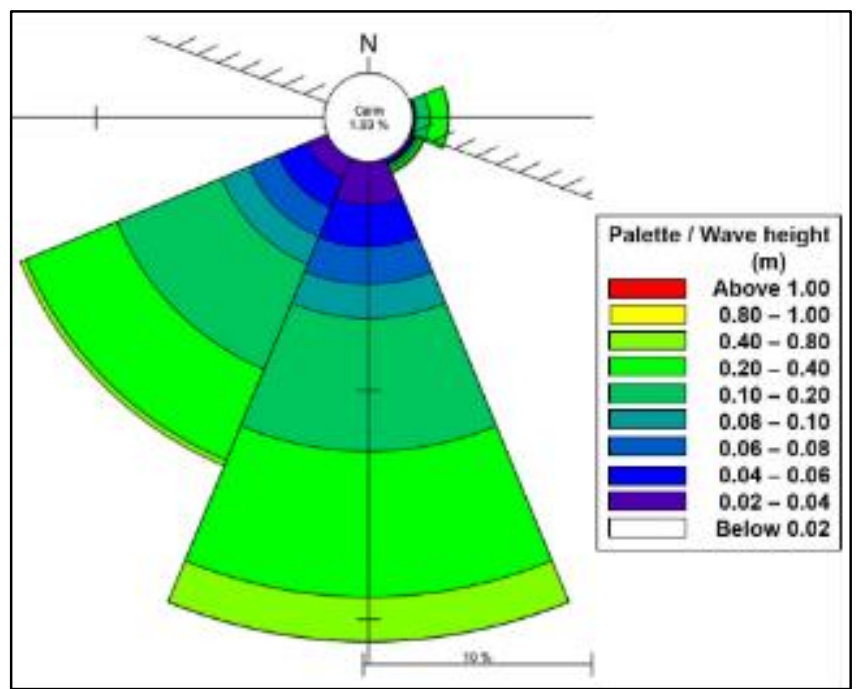

Figure 7. Rose-plot of the area. It represents the condition of wave height distribution relative to the wave direction for the years 1999 to 2006.

To make results of the numerical model comparable with the historical trend model, a framework was developed to make this comparison achievable. In both models, the shoreline position is determined by its perpendicular distance from the baseline. Hence, the baseline considered in DSAS selected for being employed in LITLINE and grid lines of the LITLINE were defined as the same of transect lines of the DSAS. Undoubtedly, the other similarity between the two models should be the initial state of the shoreline (Figure 8). Finally, based on these considerations and after operating the shoreline change simulation in both models, shoreline position in each transect line of the DSAS can be easily compared to its corresponding grid line of the LITLINE.

Based on the workflow presented in Figure 4, adjusting and running the LITDRIFT model yielded the annual sediment drift (i.e. the $Q_{1}$ in Figure 4) $9839.24 \mathrm{~m}^{3}$ for the years 1999 to 2006, while the Monitoring and Modeling Studies of Iranian Coasts (phase4Hormozgan coasts) reported the average annual drift of the area near $10,000 \mathrm{~m}^{3}$ for the same time span [60]. 


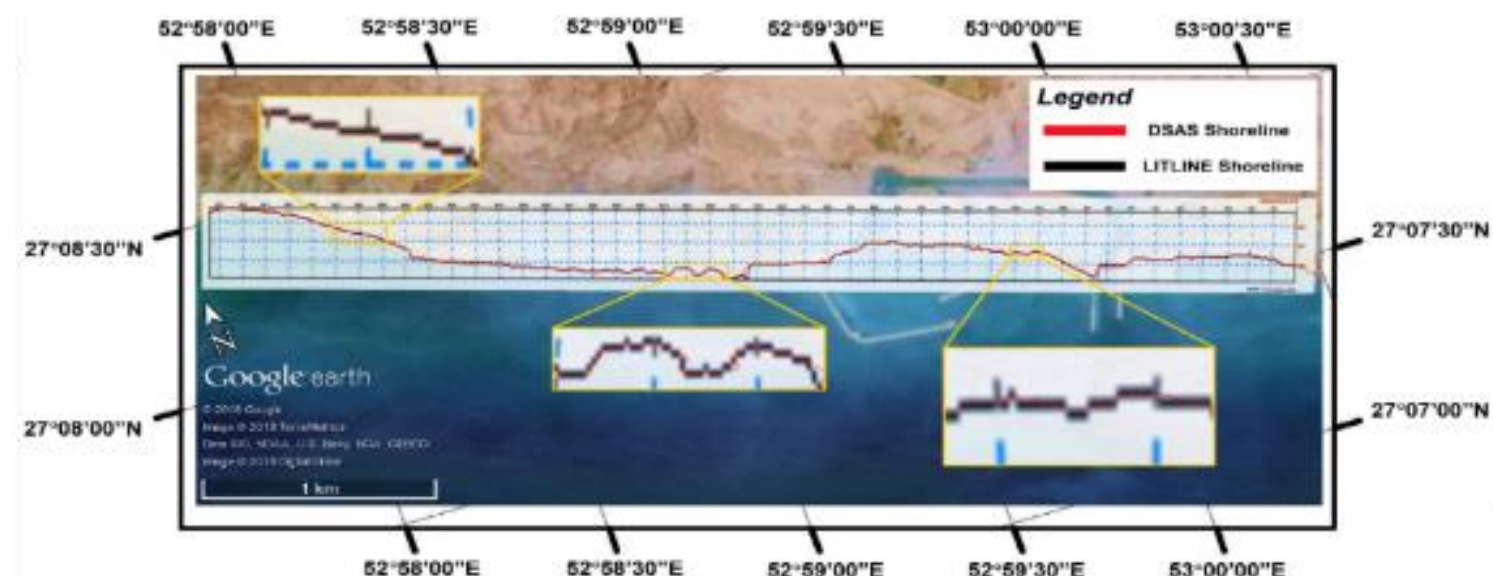

Figure 8. DSAS versus LITLINE simulated shorelines for 01/01/2005. To present more details, a video file is provided.

Furthermore, a sensitivity analysis was carried out to check if the LITDRFT model is adjusted properly. Parameters of Relative Sediment Density $(R S D)$ and Mean Grain Diameter $\left(D_{50}\right)$ was altered intentionally to a random amount ${ }^{* 2}$ to evaluate the subsequent changes in the annual drift value (Figure 9).

According to Figure 9, as it was expected by comparing the black line with the blue line and also the yellow line with the red and green lines, a decrease in $R S D$ leads to an increase in transport rate capacity. Moreover, by comparing the blue line with the red line and also the black line with the yellow line, an increase in $D_{50}$ leads to a decrease in transport rate capacity to a reasonable magnitude. Besides, since from December to March the weather events in the Persian Gulf is extreme, the transport rate in each graph was accelerated. This can be seen from the sudden jumps of the graphs at this period of time. Ultimately, through the sensitivity analysis and comparison of the calculated annual rate with the reported rate, the LITDRIFT model was considered verified.

Afterward, the sediment transport table (LINTABL) was adjusted. To compare the LINTABL results with LITDRIFT, the DHI [76] declares to prepare the LINTABL transport table file and make a straight shoreline in LITLINE. Then simulating the LITLINE in "disable evolution" mode provides an output timeseries file which can be compared with LITDRIFT results. The LINTABL rate of transport (i.e. the $Q_{2}$ in Figure 4) calculated by LITLINE was obtained $10356.57 \mathrm{~m}^{3} /$ year while the LITDRIFT rate was $9839.24 \mathrm{~m}^{3} /$ year which means the difference is poor and negligible (i.e. 5 percent).

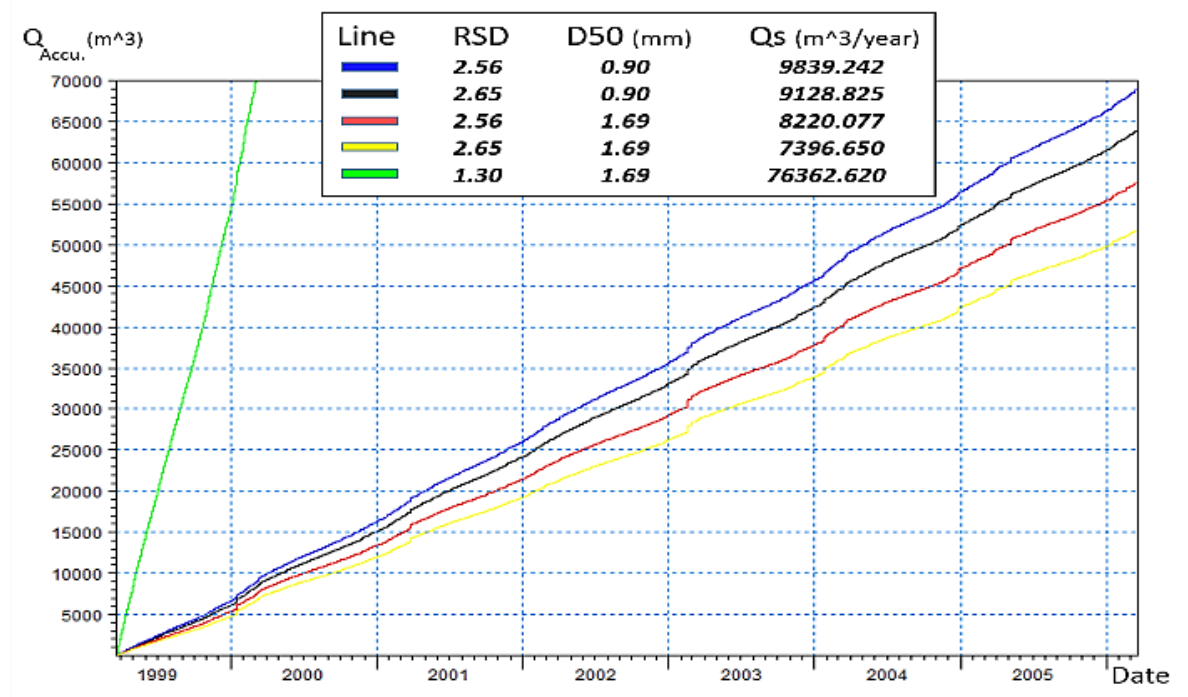

Figure 9. Sensitivity analysis of LITDRIFT model. Printed graphs represent the accumulated sediment transportation against the period of investigation. $* 2$ It should be noticed that these random values are not necessarily
the actual values of the area. The main idea of doing such analyses is to check if the output takes changes in a reasonable magnitude when a significant input is changing. 

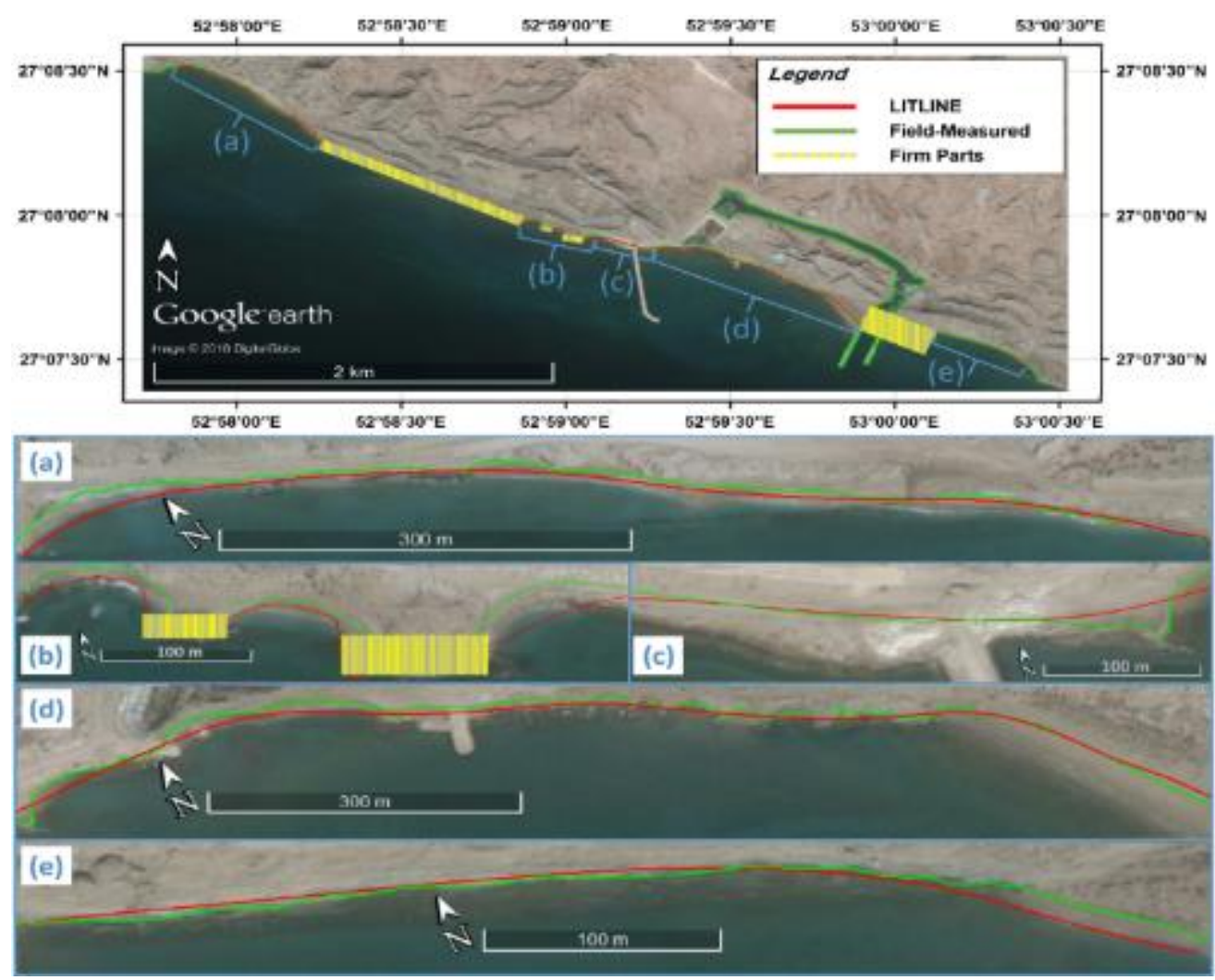

Figure 10. Result of LITLINE simulation in comparison with the field-measured shoreline. Both shorelines are associated with end of 2009. The background image is related to the available satellite imagery by closest date to the year 2009 (i.e. 10/09/2011).

According to DHI [76], to take the breakwater arms of the entrance canal (part [b] in Figure 2) into account, regarding their length they were modeled as parallel jetties. Furthermore, LITLINE does not participate deposits with $D_{50} \geq 1 \mathrm{~m}$ in sediment transportation because they would be considered as hard rock material. Consequently, the cliff part and the tombolos head parts of the shoreline (depicted in Figure 3) were modeled as revetments to prevent them from erosion. These parts were also omitted from analysis of historical trend method earlier, because of that relatively short time span of the study (see section 4.2.2).

Eventually, the shoreline evolutions corresponding to the years 2005 to 2009 were investigated by LITLINE model. The LINTABL which was tuned earlier, updated by the time-series of 2005 to 2009 waveclimate. The input parameters are given in Table 4.

Table 4. The inputted parameters of LITLINE model

\begin{tabular}{cccc}
\hline Parameter & Value & Parameter & Value \\
\hline $\begin{array}{c}\text { Angle of coast } \\
\text { normal }\end{array}$ & $\begin{array}{c}200 \\
(\mathrm{deg} .)\end{array}$ & $\begin{array}{c}\text { Additional } \\
\text { current }(0 / 1)^{*}\end{array}$ & 0 \\
\hline $\begin{array}{c}\text { Height of active } \\
\text { beach }\end{array}$ & $\begin{array}{c}2.12 \\
(\mathrm{~m})\end{array}$ & $\begin{array}{c}\text { Wind status } \\
(0 / 1)\end{array}$ & 0 \\
\hline Active Depth & $\begin{array}{c}21.61 \\
(\mathrm{~m})\end{array}$ & $\begin{array}{c}\text { Update scheme } \\
(0,1,2,3)^{* *}\end{array}$ & 3 \\
\hline Active length & $\begin{array}{c}42 \\
(\mathrm{~m})\end{array}$ & $\begin{array}{c}\text { Sediment } \\
\text { Sources }(0 / 1)\end{array}$ & 0 \\
\hline Roughness & $\begin{array}{c}0.02 \\
(\mathrm{~m})\end{array}$ & $\begin{array}{c}\text { Modify Q-Alfa } \\
(0 / 1)\end{array}$ & 1 \\
\hline
\end{tabular}

\begin{tabular}{cccc}
\hline $\begin{array}{c}\text { Mean grain } \\
\text { diameter }\end{array}$ & $\begin{array}{c}0.9 \\
(\mathrm{~mm})\end{array}$ & $\begin{array}{c}\text { Maximum } \\
\text { Courant number }\end{array}$ & 1 \\
\hline Fall velocity & $\begin{array}{c}0.05 \\
(\mathrm{~m} / \mathrm{s})\end{array}$ & $\begin{array}{c}\text { Crank-Nicolson } \\
\text { factor }\end{array}$ & 0.25 \\
\hline $\begin{array}{c}\text { Geometrical } \\
\text { spreading }\end{array}$ & 0.193 & $\begin{array}{c}\text { Diffraction Pts. } \\
\text { behind structures }\end{array}$ & 56 \\
\hline $\begin{array}{c}\text { Ref. Depth } \\
\text { height/angle }\end{array}$ & $\begin{array}{c}\text { 10 } \\
(\mathrm{m})\end{array}$ & $\begin{array}{c}\text { No. of specified } \\
\text { calculation Pt. }\end{array}$ & 1 \\
\hline Spreading factor & 0.5 & $\begin{array}{c}\text { specified cal. } \\
\text { position }\end{array}$ & 200 \\
\hline * Value of 0 indicates that no additional current exist and value \\
of 1 indicates the existence of it. \\
** The 0, 1, 2 and 3 values respectively are referred to "disable \\
$\begin{array}{l}\text { coastline evolution", "update by time interval", "update by } \\
\text { duration steps" and "update continuously" conditions of } \\
\text { morphological update scheme. }\end{array}$ \\
\hline
\end{tabular}

Once the LITLINE model simulated the shoreline change of 2005 to 2009, its 2009 shoreline position was compared to the field-measured shoreline (Figure 10) to evaluate the validation of the results. As it can be seen from Figure 10, in most parts, the LITLINE shoreline passes smoothly throughout the fieldmeasured shoreline.

In each grid line, movement of shoreline was divided by the time elapsed between the initial and the final state of shoreline position. Through this operation, a linear estimation for the rate of change was made based on LITLINE model. DSAS model uses the same method to calculate the EPR in each transect line. 


\section{Results}

The shoreline change rates of studied area were obtained from the DSAS model in EPR and LRR approaches. Another rate of change was calculated based on the LITLINE simulation (LITLINE-derived rate of change). Therefore, by updating the 2005 shoreline position via each rate of change, three estimates for the shoreline position in 2009 were achieved.

Comparison between the field-measured and estimated shorelines, and also between the real and computed change rates of studied area are presented in Figure 11. The net movement of the field-measured shoreline
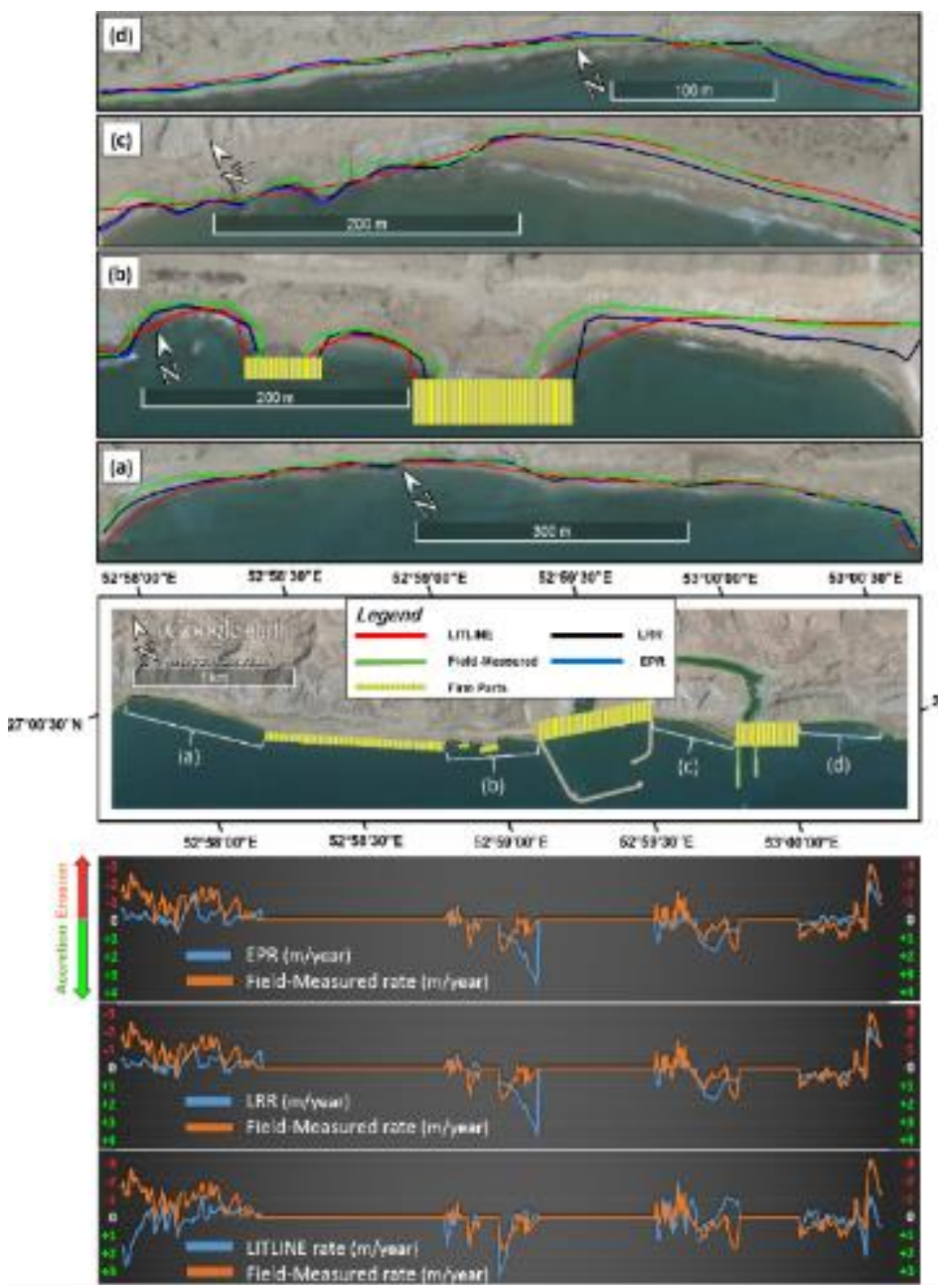

Figure 121. Comparison of: the field measured with the predicted shorelines (at the top and in the middle), and the real with the computed change rates of studied shoreline (at the bottom). The positive values indicate accretion, while the negative values indicate erosion.

relative to the shoreline position in 2005, divided by the time of this movement in years, provided an approximation for the real rate of shoreline change in this area. It should be noticed that since there is no satellite image available for the time which comparison of estimated shorelines was taken place (i.e. 12/31/2009), the image No. 5 from Table 3 (i.e. 02/15/2015) was used as the background of Figure 11 to indicate shorelines location, visually.
To assign an appropriate single rate of change to each coastal landform, performing a visual judgment on Figure 11 could be enough for decision making. Although, in order to quantify the comparison, a statistical analysis was carried out based on measuring differences between the field-measured and the predicted shorelines in each grid line. In Table 5, precision of predicted shorelines (or corresponding rates of change) relative to each other is presented. The landforms mentioned in Table 5, and comparison of the change rates in a single graph are depicted in Figure 12.

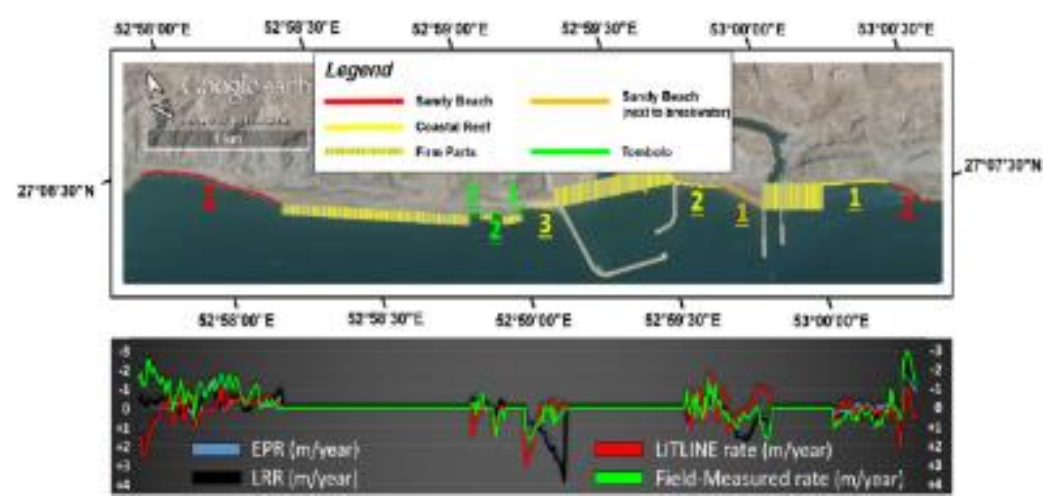

Figure 112. Parts of the landforms in Table 5 (at the top), and comparison of the shoreline change rates (at the bottom).

Table 5. Quantitative comparison between the change rates accuracy relative to each other. (E.g. the LITLINE rate of change was 1.25 times worse than the EPR in predicting the Part1 of the sandy beach while it was 0.186 times better in predicting the Part2 of the coastal reef).

\begin{tabular}{ccccc}
\hline Landforms & $\begin{array}{c}\text { LITLINE } \\
\text { relative to } \\
\text { EPR (\%) }\end{array}$ & $\begin{array}{c}\text { LITLINE } \\
\text { relative to } \\
\text { LRR (\%) }\end{array}$ & $\begin{array}{c}\text { DSAS LRR } \\
\text { relative to } \\
\text { EPR (\%) }\end{array}$ \\
\hline \multirow{2}{*}{ Sandy beach } & Part1 & -125 & -191.9 & +22.9 \\
\cline { 2 - 5 } & Part2 & -44.9 & -52.3 & +4.9 \\
\hline \multirow{3}{*}{ Coastal Reef } & Part1 & -1.4 & -99.7 & +49.2 \\
\cline { 2 - 5 } & Part2 & +18.6 & -0.3 & +18.8 \\
\cline { 2 - 5 } Part3 & +68.9 & +69.5 & -2 \\
\hline $\begin{array}{c}\text { Sandy } \\
\text { (Breakwater) }\end{array}$ & $\underline{\text { Part1 }}$ & +31.5 & +29.2 & +3.2 \\
\hline \multirow{3}{*}{ Tombolo } & $\underline{\text { Part1 }}$ & +8.4 & +8.5 & -0.1 \\
\cline { 2 - 5 } & Part2 & -84.1 & -107.3 & +11.2 \\
\cline { 2 - 5 } & Part3 & -96.8 & -125 & +12.5 \\
\hline
\end{tabular}

Eventually, regarding the assigned change rates to each landform, an estimation for the shoreline position with the date similar to the image number 7 in Table 3 was made to be compared with the digitized shoreline of this satellite image (Figure 13). 


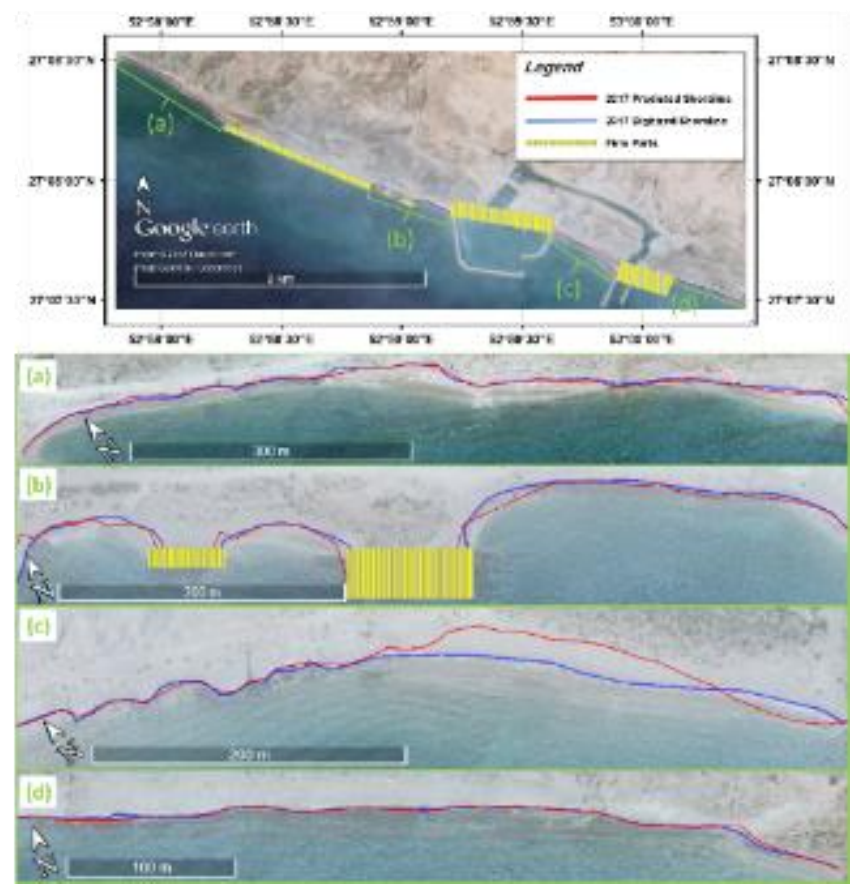

Figure 13. The estimated shoreline and the digitized shoreline associated with April 2017 satellite image (i.e. the most recent available satellite image of this area).

\section{Discussion}

Considering Table 5 and Figure 12 (or Figure 11), it was revealed that among all the computed rates of change, the LRR has provided the most accurate estimation for 6 out of 9 parts of the landforms in (decadal-scale). After that, the LITLINE-derived rate was better than the EPR and the LRR in estimating the change rates of the other three parts. Besides, at part2 of the coastal reefs, the precision of LRR is only 0.003 times better than the LITLINE-derived rate; hence, they can be considered identical in precision. Moreover, the EPR could not estimate the rate of changes better than the other models at any of these 9 parts.

Since the LITLINE model is more applicable for noncohesive materials of sand size [76, 77], then it seems if the LITLINE-derived rate could estimate the change rates of a single landform better than the other computed rates, this landform would be the sandy beaches. But, as it can be seen from Figure 11, Figure 12 or Table 5, the LRR has estimated change rates of this landform more precisely.

To explain the reason, position of the landform parts associated with the superiority of the LITLINE rate should be noticed by using Figure 12. These parts are the next to breakwater sandy beach, part 3 of the coastal reefs and part 1 of the tombolos (the underlined items in Table 5). These three parts, as well as the part 2 of the coastal reefs (which function of the LITLINE-derived rate and the LRR was considered identical), are located at the adjacency of the later-constructed breakwater arms in the year 2011.

As it was described in section 3 (Study area), the new basin's breakwater arms were constructed in 2011 while the computed shorelines and rates of change were estimated for the year 2009 to be compared with the 2009 field-measured shoreline. According to Table 3 and the modeling procedure in section 4.2.2, there is only one satellite image available before 2011, so the digitized shorelines from satellite images after 2011 were used in the calculation of the EPR and LRR. As a consequence, at these four parts, the EPR and LRR were affected by responses of the shoreline to the new breakwater arms. Ultimately, because the LITLINE model has used the dataset before construction of the new basin, the shoreline position and the rate of change derived from this model became more accurate than the LRR estimation only for these parts in 2009.

Furthermore, one of the important issues in evaluating the shoreline changes is determining the parts which are prone to erosion. The change rates presented in Figure 11 and Figure 12 revealed that in regard to erosion or accretion, the LRR and EPR graphs are following the field-measured rate much more than the LITLINE-derived rate (notably at the parts related to the sandy beach landform).

Moreover, to clarify the final prediction (i.e. estimation for the shoreline position in 2017) accuracy which is carried out by statistical analysis of Figure 13, the average differences between the predicted and the digitized shorelines for each coastal landform were computed. Results showed that the framework used in this study has predicted the shoreline position at these landforms by the average difference of $1.1 \mathrm{~m}$ for coastal reefs, $1.5 \mathrm{~m}$ for the sandy beaches, $2.7 \mathrm{~m}$ for the tombolos and $14.7 \mathrm{~m}$ for the sandy beach that is next to the old breakwater arm. Although, the idea behind analyzing the studied shoreline evolutions by the DSAS model is to determine its decadal trend, not to predict the exact position of shoreline at a given time (e.g. 2017).

On the other hand, according to Figure 14, at most parts of the studied shoreline, the NSM and the SCE are almost equal to each other over the years of 2005 to 2015. This situation somehow means, over the period of investigation at these parts the shoreline has been constantly under erosion or accretion. In conclusion, it is true that extending the prior trend to predict the future position of shoreline might include some uncertainties, but results of this study showed that at the parts which the NSM and the SCE are closer together, the predicted shoreline is much closer to its actual position. For example, the average difference between the predicted and the actual position of the 2017-shoreline is $1.5 \mathrm{~m}$ at sandy beach parts, while its corresponding difference of NSM and SCE in Figure 14 is relatively smaller than the tombolo parts with the 


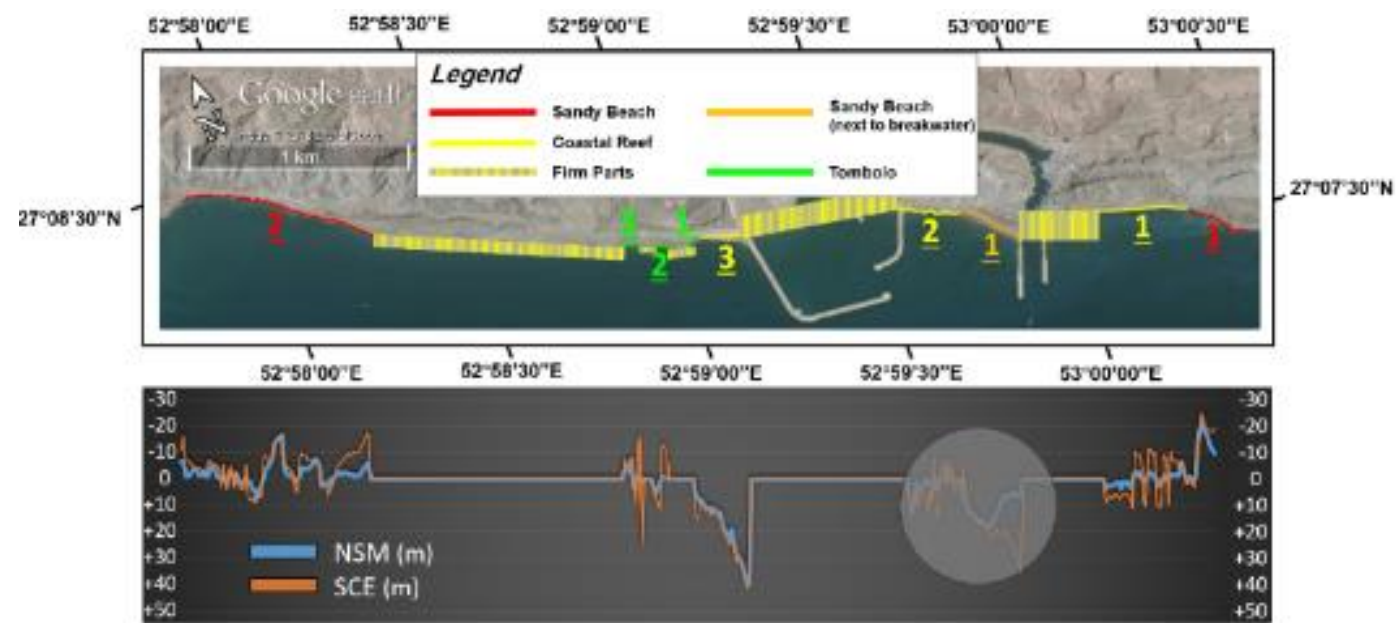

Figure 14. Comparison of NSM with SCE from 2005 to 2015. The shaded circle indicates parts of the shoreline which in them the LITLINE-derived rates were used for their 2017 prediction.

average difference of 2.7 meters in its predicted and actual position.

In addition, the large distance $(14.7 \mathrm{~m})$ between 2017 predicted and digitized shorelines at the sandy beach next to the old breakwater arm can be because of using the LITLINE-derived rates in prediction of this part. The LITLINE model has simulated shoreline changes for the time span of 2005 to 2009 and based on this simulation, an estimation for shoreline change rates was made to predict its 2017 position. Consequently, the sediment sources due to constructing the new breakwater arms in 2011 were not considered in the LITLINE modeling procedure which had a direct impact on the condition of the downstream deposits. Furthermore, this Construction in 2011 was the reason why despite the results in Table 5, the LRR was selected to predict the part 3 of coastal reefs position in 2017, instead of the LITLINE-derived rates.

\section{Conclusions}

Evolution of a $5.5 \mathrm{~km}$ shoreline in the surrounding of Javad Al-Aemmeh fishery port was investigated to determine its decadal-scale rate of change. Since the studied area has experienced consecutive constructions in its region, a framework was developed to compare results of the DSAS model with the LITLINE model which are totally based on different approaches of historical trend and numerical modeling, respectively. Results showed that, under the modeling circumstances of this study, the LRR which benefits from the historical trend method would determine the studied shoreline evolutions better than the one-line numerical method (even at sandy beach landform). However, the LRR is not accurate enough in areas which are directly influenced by human interventions. Therefore, applying other methods (like numerical modeling) to cover this shortage seems to be quite essential. Moreover, it was realized that predicting the future position of studied shoreline through the historical trend method is more reliable in case the NSM and the
SCE are identical. Also in regard to determining the erosion-prone areas, the LRR was better than the EPR, and the LITLINE-derived rate had the least accuracy relative to the two others.

Eventually, at the parts of the shoreline concerned with the LITLINE model, to obtain a more precise estimation for the shoreline position in 2017, it is recommended to build a representative wave climate to simulate the changes instead of predicting them via the derived rate. Another recommendation is, including the field-measured shoreline in the calculation of DSAS model and comparing the results with those presented in this study. In the end, it is highly recommended to study the shoreline change issue from different points of view (by applying different approaches) in order to cover the deficiencies of each other. This would result in presenting more efficient information to coastal managers and decision makers about future changes in shorelines position.

\section{Acknowledgment}

The first author wishes to thank Dr. Mohammadreza Sajjadi for improving the article structure.

\section{References}

1. Bird, E.C.F., (1985), Coastline changes. A global review.

2. Addo, K.A., Jayson-Quashigah, P. and Kufogbe, K., (2011), Quantitative analysis of shoreline change using medium resolution satellite imagery in Keta, Ghana, Marine Science, Vol.1(1), p.1-9.

3. Alesheikh, A.A., Ghorbanali, A. and Nouri, N., (2007), Coastline change detection using remote sensing, International Journal of Environmental Science \& Technology, Vol.4(1), p.61-66.

4. Samaras, A.G. and Koutitas, C.G., (2012), An integrated approach to quantify the impact of watershed management on coastal morphology, Ocean \& coastal management, Vol.69, p.68-77. 
5. Stanchev, H., et al., (2018), Analysis of shoreline changes and cliff retreat to support Marine Spatial Planning in Shabla Municipality, Northeast Bulgaria, Ocean \& Coastal Management, Vol.156, p.127-140.

6. Hapke, C.J., et al., (2010), National assessment of shoreline change: Historical shoreline change along the New England and Mid-Atlantic coasts, US Geological Survey.

7. El-Asmar, H.M., Hereher, M.E. and El Kafrawy, S.B., (2013), Surface area change detection of the Burullus Lagoon, North of the Nile Delta, Egypt, using water indices: A remote sensing approach, The Egyptian Journal of Remote Sensing and Space Science, Vol.16(1), p.119-123.

8. Oyedotun, T.D., (2014), Shoreline geometry: DSAS as a tool for historical trend analysis, British Society for Geomorphology, Geomorphological Techniques. ISSN, p.2047-0371.

9. Gould, A.I., Kinsman, N.E. and Hendricks, M.D., (2015), Guide to projected shoreline positions in the Alaska Shoreline Change Tool, Division of Geological \& Geophysical Surveys Miscellaneous Publication, Vol.158.

10. Davidson, M.A., et al., (2017), Annual prediction of shoreline erosion and subsequent recovery. Coastal Engineering, Vol.130, p.14-25.

11. Hagenaars, G., et al., (2018), On the accuracy of automated shoreline detection derived from satellite imagery: A case study of the sand motor mega-scale nourishment, Coastal Engineering, Vol.133, p.113125.

12. Gopikrishna, B. and Deo, M., (2018), Changes in the shoreline at Paradip Port, India in response to climate change, Geomorphology, Vol.303, p.243-255. 13. Davidson, M., Lewis, R. and Turner, I., (2010), Forecasting seasonal to multi-year shoreline change, Coastal Engineering, Vol.57(6), p.620-629.

14. Sorensen, R.M., (2005), Basic coastal engineering, Vol.10, Springer Science \& Business Media.

15. Kudale, M., (2010), Impact of port development on the coastline and the need for protection.

16. Briand, M.H.G. and Kamphuis, J.W., (1990), A micro-computer based Quasi 3-D sediment transport model, Coastal Engineering Proceedings, Vol.1(22).

17. Larson, M., Kraus, N.C. and Hanson, H., (1990), Decoupled numerical model of threedimensional beach change, Coastal Engineering Proceedings, Vol.1(22).

18. Shimizu, T., Nodani, H. and Kondo, K., (1990), Practical application of the three-dimensional beach evolution model. Coastal Engineering Proceedings, Vol.1(22).

19. Siegle, E., Huntley, D.A. and Davidson, M.A., (2002), Modelling water surface topography at a complex inlet system-Teignmouth, UK, Journal of Coastal Research, Vol.36(sp1), p.675-685.

20. Lumborg, U. and Windelin, A., (2003), Hydrography and cohesive sediment modelling: application to the Røm $\phi$ Dyb tidal area. Journal of Marine Systems, Vol.38(3-4), p.287-303.

21. Merritt, W.S., Letcher, R.A. and Jakeman, A.J, (2003), A review of erosion and sediment transport models, Environmental Modelling \& Software, Vol.18(8-9), p.761-799.

22. Lumborg, U. and Pejrup, M., (2005), Modelling of cohesive sediment transport in a tidal lagoon-An annual budget, Marine Geology, Vol.218(1-4), p. 1-16.

23. Ellis, J. and Stone, G.W., (2006), Numerical simulation of net longshore sediment transport and granulometry of surficial sediments along Chandeleur Island, Louisiana, USA, Marine Geology, Vol.232(34), p.115-129.

24. Van Maren, D., (2007), Grain size and sediment concentration effects on channel patterns of silt-laden rivers, Sedimentary Geology, Vol.202(1-2), p.297-316.

25. Hu, K., et al., (2009), A 2D/3D hydrodynamic and sediment transport model for the Yangtze Estuary, China, Journal of Marine Systems, Vol.77(1-2), p.114136.

26. Kamalian, R. and Safari, H., (2012), Impact of Changes in Caspian Sea Levels on Sedimentation in Nowshahr Port. In: 10th International Conference on Coastal, Ports and Marine Structures, Port and Maritime Organization, Tehran. Iran. (In Persian)

27. Eisaei Moghadam, E. and Hakimzadeh, H., (2015), Numerical simulation of waves and coastal flows in Ramine Port. In: 17th Conference on Marine Industries, Iranian Association of Naval Architecture and Marine Engineering. Kish Island. Iran. (In Persian) 28. Khalifa, A., Soliman, M. and Yassin, A., (2017), Assessment of a combination between hard structures and sand nourishment eastern of Damietta harbor using numerical modeling, Alexandria Engineering Journal, Vol.56(4), p.545-555.

29. Deguchi, I. and Sawaragi, T., (1988), Effects of structure on deposition of discharged sediment around rivermouth, Coastal Engineering Proceedings, Vol.1(21).

30. Rosati, J.D. and Kraus, N.C., (1999), Advances in Coastal Sediment Budget Methodology- With Emphasis on Inlets, Shore \& Beach, Vol.67(2), p.5665.

31. Suresh, P. and Sundar, V., (2011), Comparison between measured and simulated shoreline changes near the tip of Indian peninsula, Journal of HydroEnvironment Research, Vol.5(3), p.157-167.

32. Tajziehchi, M. and Shariatmadari, D., (2012), The coastline equation in regard to the distance of the Impermeable submerged breakwater to the coast. In: The 10th International Conference on Coasts, Ports 
and Marine Structures, Ports and Maritime Organization, Tehran. Iran. (In Persian)

33. Saengsupavanich, C., (2013), Detached breakwaters: communities' preferences for sustainable coastal protection, Journal of environmental management, Vol.115, p.106-113.

34. Kristensen, S.E., et al., (2013), Hybrid morphological modelling of shoreline response to a detached breakwater, Coastal Engineering, Vol.71, p.13-27.

35. Noujas, V., Thomas, K. and Badarees, K., (2016), Shoreline management plan for a mudbank dominated coast, Ocean Engineering, Vol.112, p.4765.

36. DeWitt, H. and Weiwen Feng, J., (2002), SemiAutomated construction of the Louisiana coastline digital land-water Boundary using landsat TM imagery, Louisiana's Oil Spill Research and Development Program, Louisiana State University, Baton Rouge, LA, 70803.

37. Alesheikh, A., Sadeghi Naeeni, F. and Talebzade, A., (2003), Improving classification accuracy using external knowledge. GIM international, Vol.17(8), p.12-15.

38. Naeimi Nezamabadi, A., Ghahroudi Tali, M. and Servati, M., (2010), Monitoring Coastal Changes and Geomorphologic Landforms of Persian Gulf Using Remote Sensing and Geographic Information System (Case Study: Assaluyeh Coastal Area), Geographical Space, Vol.10(30), p.45-61. (In Persian)

39. Ardeshiri Lajimi, M. and Moradi, A., (2014), Compilation and statistical analysis of coastline changes in Qeshm Island using the DSAS tool in ArcGIS software. In: 1st National Conference on Sustainable Development of Sea, Marine Science and Technology, University of Khorramshahr: Khorramshahr. Iran. (In Persian)

40. Baharlouei, M. and Maafi Gholami, D., (2016), DSAS as a tool for analyzing the historical trend. In: 1st National Conference on Natural Resources and Sustainable Development in Central Zagros, Shahrekurd University, Iran. Shahrekurd. (In Persian) 41. Ari, H.A., et al., (2007), Determination and control of longshore sediment transport: a case study, Ocean Engineering, Vol.34(2), p.219-233.

42. Rajasree, B., Deo, M. and Nair, L.S., (2016), Effect of climate change on shoreline shifts at a straight and continuous coast. Estuarine, Coastal and Shelf Science, Vol.183, p.221-234.

43. Nielsen, P., et al., (2001), Infiltration effects on sediment mobility under waves. Coastal Engineering, Vol.42(2), p.105-114.

44. Li, L., et al., (2002), modelling groundwater effects on swash sediment transport and beach profile changes, Environmental Modelling \& Software, Vol.17(3), p.313-320.

45. Leroy, S.A.G., et al., (2007), River inflow and salinity changes in the Caspian Sea during the last
5500 years, Quaternary Science Reviews, Vol.26, p.25-28.

46. Allyev, A.S., (2010), The Last sharp rise of the level of the Caspian Sea and its consequence in the coastal zone of Azerbaijan the Caspian Region (Environmental, Consequences of the climate change). In: Proceedings of the International Conference, University of Moscow. Russia.

47. Hosseininejad, S.H., (2006), Investigation of sediment transport in Javad Alaemmeh fishery port. In: The 7th International Conference on Coasts, Ports and Marine Structures, Port and Maritime Organization, Tehran. Iran. (In Persian)

48. Nadimi, S. and Lashtehneshaei, M.A., (2010), Investigation of erosion and sedimentation process in the pond toward Bandar-E Anzali wetland using the mathematical model. In: 5th National Congress on Civil Engineering, Ferdowsi University of Mashhad, Mashhad. Iran. (In Persian)

49. Taghvaei, P. and Ghiasi, R., (2013), Investigating the Sediment Particle Movement in Shahid Rajaee Port by Lagrangian Particle Tracking. In: 15th Conference on Marine Industries, Iranian Association of Naval Architecture and Marine Engineering, Kish Island. Iran. (In Persian)

50. Lillesand, T., Kiefer, R. and Chipman, J., (2004), Remote sensing and image interpretation, Remote sensing and image interpretation, Vol.(Ed. 5). 51. Sulis, A., et al., (2017), On the applicability of empirical formulas for natural salients to Sardinia (Italy) beaches, Geomorphology, Vol.286, p.1-13.

52. Zarifsanayei, A.R. and Zaker, N.H., (2015), Coastal Sediment Transport, Engineering Practice, A case study in The Sea of Oman, Iran. In: 10th International Congress on Civil Engineering, Tabriz University, Tabriz. Iran.

53. Jafarzadeh, E., et al., (2014), Application of LITPACK Mathematical Model in Simulation of Anzali Port Shoreline Changes after Constructing the new Breakwaters and Evaluating it using Satellite Images and GIS. In: 8th National Congress on Civil Engineering, Babol Noshirvani University of Technology, Babol. Iran. (In Persian)

54. ISNA (Iranian Students' News Agency), (2005), Manager of Gavbandi County's Javad AlAemmeh fishery port: 3,000 tons of fishes are hunted in this port annually. [cited 2005 December 25]; Available from: https://www.isna.ir/news/8410$01077 /$.

55. HFO (Hormozgan Fisheries Organization), (2015), In accordance to Government's week: Exploitation of the Javad Al-Aemmeh port's development and organizing plan (Parsian Fisheries). [cited 2015 August 2015]; Available from: http://www.shilathormozgan.ir/News_Detail.aspx?Id= 274. 
56. Jihad, (1984), An Introduction on Javad AlAemmeh fishery port project. Bimonthly Journal of Jihad, Vol.68(1), p.30-39.

57. TNA (Thinking New Approach), (2018), Supervision of Construction Operations of Javad-ol Aemeh Fishing Port Development Plan. [cited 2018 October 20]; Available from: http://www.tna$\underline{\text { co.ir } / \text { projects/ProjectDetail.aspx } ? \text { code }=\mathrm{MzM}=\& \text { catCo }}$ $\mathrm{de}=\mathrm{Mw}==$.

58. HFO (Hormozgan Fisheries Organization), (2018), [cited 2018 October 20 ]; Available from: http://www.shilathormozgan.ir/Page.aspx?Type=39.

59. NCC (National Cartographic Center of Iran), (2018), Hydrography and Tidal Management. [cited 2018 October 20 ]; Available from: http://iranhydrography.ncc.org.ir/homepage.aspx?site $=$ iranhydrography.ncc.org\&tabid=6144\&lang=fa-IR.

60. PMO (Ports and Maritime Organization), (2018), Monitoring and modeling study of Iranian coasts: Phase4-Hormozgan coasts. [cited 2018 October 23]; Available from: https://irancoasts.pmo.ir/en/phases/phase4.

61. Kusimi, J.M. and Dika, J.L., (2012), Sea erosion at Ada Foah: assessment of impacts and proposed mitigation measures, Natural hazards, Vol.64(2), p.983-997.

62. Watanabe, Y. and Mori, N., (2008), Infrared measurements of surface renewal and subsurface vortices in nearshore breaking waves, Journal of Geophysical Research: Oceans, Vol.113(C7).

63. Mancini, F., et al., (2013), Using unmanned aerial vehicles (UAV) for high-resolution reconstruction of topography: The structure from motion approach on coastal environments. Remote Sensing, Vol.5(12), p.6880-6898.

64. Mason, D., et al., (1999), Measurement of recent intertidal sediment transport in Morecambe Bay using the waterline method, Estuarine, Coastal and Shelf Science, Vol.49(3), p.427-456.

65. Mason, D., et al., (1995), Construction of an inter-tidal digital elevation model by the 'WaterLine'Method, Geophysical Research Letters, Vol.22(23), p3187-3190.

66. Liu, Y., et al., (2013), Quantitative analysis of the waterline method for topographical mapping of tidal flats: a case study in the Dongsha sandbank, China. Remote Sensing, Vol.5(11), p 6138-6158.

67. Bird, C.O., Bell, P.S. and Plater, A.J., (2017), Application of marine radar to monitoring seasonal and event-based changes in intertidal morphology. Geomorphology, Vol.285, p.1-15.

68. Thieler, E.R., et al., (2009), The Digital Shoreline Analysis System (DSAS) version 4.0-an ArcGIS extension for calculating shoreline change, US Geological Survey.

69. Ozturk, D. and Sesli, F.A., (2015), Shoreline change analysis of the Kizilirmak Lagoon Series, Ocean \& Coastal Management, Vol.118, p.290-308.
70. Winarso, G. and Budhiman, S., (2001), The potential application remote sensing data for coastal study. In: the 22nd Asian conference on remote sensing, 5-9 November 2001. Centre for remote imaging, sensing and processing (CRISP), National University of Singapore. Singapore.

71. Guariglia, A., et al., (2006), A multisource approach for coastline mapping and identification of shoreline changes, Annals of geophysics, Vol.49(1).

72. Jonah, F., et al., (2016), Shoreline change analysis using end point rate and net shoreline movement statistics: An application to Elmina, Cape Coast and Moree section of Ghana's coast. Regional studies in marine science, Vol.7, p.19-31.

73. Brown, M., (2014), Digitizing HighResolution Coastlines in Google Earth. [cited 2014 August 4]; Available from: http://marinedataliteracy.org/margis/ge_shapes/ge_sha pes.htm.

74. Manca, E., et al., (2013), Shoreline evolution related to coastal development of a managed beach in Alghero, Sardinia, Italy, Ocean \& coastal management, Vol.85, p 65-76.

75. Morton, R.A., Miller, T.L. and Moore, L.J., (2004), National assessment of shoreline change: Part 1 Historical shoreline changes and associated coastal land loss along the US Gulf of Mexico, US Geological Survey.

76. DHI (Danish Hydraulic Institute), (2007), LITLINE: Coastline evolution; LITLINE user guide.

77. DHI (Danish Hydraulic Institute), (2012), LITPACK: An Integrated Modelling System for Littoral Processes And Coastline Kinetics; Short Introduction and Tutorial. 